Relations industrielles

Industrial Relations

\title{
Business « Organizes »: The Early Years in Québec
}

\section{James Thwaites}

Volume 36, numéro 2, 1981

URI : https://id.erudit.org/iderudit/029158ar

DOI : https://doi.org/10.7202/029158ar

Aller au sommaire du numéro

\section{Éditeur(s)}

Département des relations industrielles de l'Université Laval

\section{ISSN}

0034-379X (imprimé)

1703-8138 (numérique)

Découvrir la revue

\section{Citer cet article}

Thwaites, J. (1981). Business « Organizes »: The Early Years in Québec. Relations industrielles / Industrial Relations, 36(2), 403-411.

https://doi.org/10.7202/029158ar

Tous droits réservés @ Département des relations industrielles de l'Université Laval, 1981
Ce document est protégé par la loi sur le droit d'auteur. L'utilisation des services d'Érudit (y compris la reproduction) est assujettie à sa politique d'utilisation que vous pouvez consulter en ligne.

https://apropos.erudit.org/fr/usagers/politique-dutilisation/ 


\title{
Business "Organizes"
}

\section{The Early Years in Québec}

\author{
James Thwaites
}

The period from 1896 to 1915 can be characterized generally as one of economic boom, industrial and commercial expansion, and significant changes in trade unionism. What is less known is that it was also a period of the establishment and consolidation of employers' associations. This collective impulse toward employers' associations was doubtless encouraged by specific intercompany problems such as the creation of new markets and the shortage of skilled manpower. It might also have been thought necessary in view of the Federal Government's decision to found a Department of Labour (1900) and a similar provincial decision shortly afterward: both henceforth determined to have their "say" in an organized way on labourmanagement questions. And it was certainly stimulated by the increasing tendancy of unions to use the strike as an integral part of the collective bargaining process ${ }^{1}$.

For a variety of reasons, business "organized". Numerous associations appeared or consolidated. Unfortunately, the information most of them left is scanty. Some, luckily, have left partial records in the sources used for this study, and they reveal enough detail to put together the essential elements of an overall picture.

Evidently, these associations can be subdivised according to their specific roles in the business community. Gérard Dion, for example, provides us with two major classifications:

General Employers’ Associations («Groupements patronaux au sens large»),

True Employers’ Associations («Groupements patronaux proprement dits»).

The essential difference between the two, according to Dion, is the industrial relations function. The first classification includes, thus, such allencompassing associations as the Chambers of Commerce, where membership is on an individual basis. The second is subdivided into three categories:

- THWAITES, James, professeur, Département des relations industrielles, Université Laval.

1 A total of 391 strikes took place from 1896 to 1915, indicating an intensity of labourmanagement conflict unusual for the time. According to Larocque only 169 strikes were recorded for the entire period from 1851 to 1896: Paul LAROCQUE, «Les grèves», in Noël Bélanger et collab., Les travailleurs québécois: 1851-1896, Montréal, P.U.Q., 1973, pp. 133 à 149.

2 DION, Gérard, «Les groupements patronaux: essai de classification», Relations industrielles/Industrial Relations, vol. 8, no 4, septembre 1953, pp. 350-360. I have slightly altered Gérard Dion's terminology its English version. 


\begin{abstract}
All-purpose inter-sectorial or sectorial associations,
Cohesive sectorial associations,

Employers' movements.
\end{abstract}

The first and second are directly linked to specific sectors of the economy. An example of the first would be the Canadian Manufacturers' Association, and the latter the "Association des manufactures de chaussures» of Quebec City. What differentiates them, in the Dion model, is the degree of implication in industrial relations, the first being largely advisory and the second being much more direct, as in the case of a common front of employers for purposes of negotiation. The third category pertains particularly to associations based on Catholic Social Doctrine. It seems linked to "General Employer's Associations", by its composition, but to "True Employers' Associations"' through its preoccupations with industrial relations (as interpreted by the Catholic Church).

In terms of the Dion model, the associations studied in this article belong to both classifications, but exclude the last category for lack of information in present sources. The model is important, but should be taken here as an overall indication. Its most significant application pertains to subsequent periods, as regards specifically the industrial relations function. The reason for this is that, during the years under study, such associations were involved in experimentation and definition of their roles because of new challenges. Indeed, several governments were also involved in the process of experimentation and the definition of their roles as the contemporary debate over arbitration reveals. This is true of such countries as France, Great Britain and New Zealand as well as Canada ${ }^{3}$. The relevant French law was passed in 1892. The British law dates from 1896, and that of New Zealand from 1894. The comparable Canadian legislation dates from 1900 on the federal level and 1901 in the case of Quebec. Amendments followed in all cases. It should also be noted that these laws were far from uniform from country to country. Thus, it should not be surprizing that the employers' associations also tended to experiment in this area.

The Canadian Manufacturers' Association is by far the best documented of these employers' associations in Quebec and on the national level, but we also have material on the Chambers of Commerce, the Board of Trade, the Builders' Exchange, and others. The interests of the C.M.A., for example, were vast and it was well-organized. Originally established in 1871, as the Manufacturers' Association of Ontario, the C.M.A. went through a major reorganization in 1900 , permitting it to move onto the national level, incorporating other trade associations and a ready-made unit in Montreal in the Independent Montreal Manufacturers' Association. Quebec City was added in $1902^{4}$. The membership leaped from 123 in 1900 to 3,043 in 1914. Among the latter, 774 were in Quebec provinces.

3 GUILBAULT, Jacques, «Les lois québécoises de conciliation et d'arbitrage», $L a$ Revue du Barreau de la province de Québec, tome II, no 5, mai 1951, pp. 221-245.

4 The Canadian Manufacturers' Association, The First Hundred Years, (s.l.n.d.), pp. 3-4 (In future: C.M.A., First Hundred Years).

5 Canada, Labour Gazette, vol. 15, August 1914, pp. 265-266. 
During the years before the first World War, the C.M.A. developed numerous specialized committees in response to business needs, including, transportation, foreign markets, the tariff and law. From 1900 on, the C.M.A. maintained a type of consular service for contacts overseas 6 , and even launched a full-scale trading mission to Britain and France in 1905 in search of markets". In 1907, a "representative" was appointed to Ottawa to help correct "Ottawa's legislative fecundity and increasing bureaucratic bent." 8

Although the origins of the Chamber of Commerce go back beyond our period as well, the province-wide Chamber had its origins in $1909^{9}$, and the various Chambers in the Eastern Townships federated in 1911 or $1912^{10}$. Montreal, Quebec, Levis, and probably other cities had active Chambers during the period" ${ }^{\prime \prime}$. With the exception of Quebec, however, relatively little is known of them. They were primarily concerned with local events ${ }^{12}$, probably because they embraced a number of business with various needs, as opposed to specific trade associations like the Builders' Exchanges which could afford more unity of policy and action.

The Chamber of Commerce is indicated interestingly as FrenchCanadian in character and outlook, the French counterpart of the Board of Trade and other predominantly English-speaking bodies ${ }^{13}$. O.A. Perrault, president of the Montreal branch, described the organization as follows: «Elles jouent pour la classe bourgeoise, le rôle que jouent les unions ouvrières pour le prolétariat. Leur création répondit pour les hommes d'affaires à un besoin analogue à celui qui déterminera l'organisation des syndicats ouvriers. $\gg 14$

Of the other associations we know considerably less. The Boards of Trade, the first founded in 1822, federated to create a Canadian Board in $1909^{15}$. It is described as composed of the wealthiest merchants and business men, and very active in Canadian development ${ }^{16}$. The Contractors' Liberal Club was formed in 1894 in Montreal, and the Montreal Builders' Exchange, in $1897^{17}$. The Canadian Mining Association appeared in $1898^{18}$.

6 C.M.A., First Hundred Years, p. 10.

Ibid., p. 8-9.

8 Ibid., p. 10. See also Labour Gazette, vol. 8, October 1907, p. 439.

9 Labour Gazette, vol. 10, June 1910, p. 1350, reference to second annual meeting. See also La Patrie, July 2, 1910.

10 Documents de la Session, Québec, Imprimeur de la Reine, vol. 46, no III, 1912, Doc. 4, p. 99 (In future: $D S$ ).

11 Cf. F. OUELLET, Histoire de la Chambre de commerce de Québec 1809-1959, Québec, Faculté de Commerce, Université Laval, 1959, 105 p.; P.G. ROY, La Chambre de commerce de Lévis 1872-1947, Lévis, s.a., 1947, 120 p.

12 La Patrie, July 2, 1910. See also F. OUELLET, Chambre de commerce, p. 15.

13 La Patrie, July 2, 1910.

14 Ibid.

15 Labour Gazette, vol. 9, May 1909, p. 1170.

16 La Patrie, July 2, 1910.

17 La Gazette du travail, vol. 6, September 1905, pp. 298-299.

18 Labour Gazette, vol. 9, April 1909, p. 1113 ff, reference. 
The Quebec Association des manufactures de chaussures was created in 1900, and the Montreal Employing Printers' Club in 1901 ${ }^{19}$. The Quebec Master Printers' Association and the Montreal Marble and Granite Employers' Association were founded in $1903^{20}$. The Canadian National Association of Builders' Exchanges was organized in about 1909 and professed a two-year growth of from two to 12 branches by $1911^{21}$. Numerous other bodies were launched during these years, as well, among retail merchants and other interest groups. It was indeed an age of organization.

Le moniteur du commerce, the official organ of the Montreal Chamber, is one of our best indices of the conscience of business. It was steeped in the tradition of 'rugged individualism'. Editor Stanislas Côté left no doubt about the Chamber's position on strikes, labour unionism, socialism and all the other 'ills' that beset the society of his time. He was also a vociferous advocate of the philosophy, "À chacun le produit de son travail». This was the way in which our society had developed, he argued, and the way it would continue $^{22}$. The world was built on individual efforts and individual rewards. The idea of equality of benefits was wrong because it inspired laziness. The State was to stay out of business' way except to protect property ${ }^{23}$. One wishes Mr. Côté had read the reports of the Quebec Factory Inspectors. Was he typical? One shudders to think so, but he seems to have been well accepted for he held his position as editor of Le moniteur du commerce for at least 25 years ${ }^{24}$.

The special business reports of La Patrie and La Presse, describing the progress of industry in various areas of the province, provide further clues to the image and thought of the business $\operatorname{man}^{25}$. The leaders are idealized as dynamic men of courage and decision, vitally important to their communities and beloved by their employees. La Patrie reaches a marvellous stage of hyperbole in its full-page Horatio Alger-type description of Rodolphe Forget, M.P., "Un Napoléon de la finance au Canada ${ }^{26}$. Other aspects of characterization vary between 'one of our own making a name' to all the trappings of imperial loyalty (eg. Forget). These happy descriptions contrast radically with articles in the same papers, doubtless by writers on the labour beat, attacking «monopoleurs», unjust contracts, unbearable working conditions and the evils of child labour.

It is in the reaction to the strike that we are truly able to guage the rapport between management and labour and to measure the impact of labour. On the local level, between firm and employee, it is very difficult to paint an overall picture. Lockouts are sometimes declared, usually in an effort to destroy the union, as in Quebec City during the 1900 conflict in the boot and shoe industry. Troops or detectives are sometimes called in, and vio-

19 La Gazette du travail, vol. 6, September 1905, p. 301.

20 Ibid., pp. 299, 301.

21 Labour Gazette, vol. II, May 1911, p. 1260.

22 Le moniteur du commerce, Chamber of Commerce, Montreal, June 26, 1903.

23 Ibid., June 19, 1903.

24 Ibid., July 16, 1909.

25 See for example, La Presse, February 24, 1898; January 22, 1898; March 19 \& 31, 1898; October 26, 1901; and La Patrie, June 26, 1909; May 21, 1910; July 2, 1910.

26 La Patrie, July 2, 1910. 
lence breaks out the odd time, as it did so brutally in Buckingham in 1906. Strike-breakers are very often used. And strikes increasingly end in failure to obtain their objectives as the period progresses. But, even if they did not usually succeed, strikes cost time, production stoppages and, therefore, inconvenience and dollars. The answer was to eliminate them. But how? Everyone attempted it, from business and government, to the unions themselves.

Le moniteur du commerce attempted to do it through rhetoric directed at the strikers and the general public. It damned the strike as a disrupter of the economy, and often linked labour agitation with United States leader$\mathrm{ship}^{27}$. Foreign interests were accused of collusion aimed at damaging Canada's well-being ${ }^{28}$. Strike leaders are charged with making political capital out of strikes, and misleading good men ${ }^{29}$. Strikes on the streetcar and railroad systems are characterized as crimes against the strikers themselves and their fellow citizens ${ }^{30}$. In one revealing editorial, Le moniteur $d u$ commerce makes a peculiar distinction between Anglo-Saxon and Latin strikes, noting that the former were only concerned with economic matters, while, "Chez les peuples latins, le syndicalisme est devenu... un instrument d'anarchie ne rêvant que la destruction de la société...» ${ }^{31}$ The solution? Canadian trade unions.

With less fire, the Canadian Manufacturers' Association came to a similar conclusion, as presented in a resolution at the annual conference in 1903: "The C.M.A. believes that Canadian labour unions should be incorporated national organizations, governed by Canadian officers and free from foreign control." 32 The Board of Trade held the same point of view as announced in the face of a heavy stevedores' strike in the port of Montreal the same year ${ }^{33}$. Canadian unions would be weaker, of course, and if in addition they were incorporated they could be attacked in the courts. The aim was obviously no more union interference.

Other C.M.A. resolutions, that year, were likewise aimed at unions. The closed shop was rejected. The contract was rejected. Wages must be a matter for employers and their employees to decide, and there was to be no restriction on the number of apprentices ${ }^{34}$. The probability of national unions wanting those very rights did not seem to strike the C.M.A. as inconsistent. Thus, labour unionism was inseparably linked with disputes and strikes, and regarded as the foe. The anti-American note of the Chamber was not lacking either in subsequent C.M.A. reports.

The Department of Labour at Ottawa came in for its share of criticism as well for having, "regard for, and exist(ing) for the interests of organized

27 For example, ibid., August 7, 1908; August 5, 1910.

28 Ibid., August 14, 1909; August 5, 1910.

29 Ibid., September 21, 1900.

30 Ibid., May 29, 1903.

31 Ibid., September 25, 1908.

32 Quoted in Labour Gazette, vol. 3, October 1903, p. 337.

33 La Presse, April 30, 1903.

34 Quoted in Labour Gazette, vol. 3, October 1903, p. 337. 
labour only", a body which, it was pointed out, represented only a small portion of Canadian workingmen ${ }^{35}$. The "Department" should be directed toward guaranteeing an adequate labour supply to keep the industrial wheels turning, and reorganized to employ "only impartial and fair minded officials" 36 . In short, the C.M.A. wanted the Department to change its role entirely and serve 'everyone's' (i.e. business') needs. The allusion to a supply of labour here, in 1903, is part of a debate as long as the next decade, namely the training and importation of skilled labour.

The need was genuine. The Association started circulating a list of employees needed by member companies the following year ${ }^{37}$, and at the same time founded a technical education committee to study the question of supply of skilled domestic labour ${ }^{38}$. Three years later a special labour agent was appointed in Britain to increase the overseas supply ${ }^{39}$.

The Toronto branch of the C.M.A. launched a project, the first we know of, to found a scheme for the education of mechanics in $1902^{40}$, and the C.M.A.'s Technical Education Committee, mentioned above, set out in 1904 to look into the problem. In Montreal, in 1907, results were forthcoming. The Montreal Technical Institute was opened for classes through the joint efforts of the Montreal branch of the C.M.A. and the Mechanics' Institute ${ }^{41}$. The same year a federal committee of inquiry was requested by the C.M.A. and the Dominion Trades and Labour Congress, in cooperation with some 28 branches of the Board of Trade ${ }^{42}$. Quebec was concerned with the same question during the 1907 session, and opened the Montreal Technical School the following year ${ }^{43}$.

In view of federal inaction, however, the C.M.A. offered to form its own committee to study the nation's technical education needs in $1908^{44}$. Nothing more was heard of the plan, until the Federal Government adopted one quite similar in $1910^{45}$, doubtless the result of C.M.A. pressure. Two years later we learn that the Quebec government grant to the Polytechnical Institute of Montreal was increased ${ }^{46}$, and the following year grants were made available to the smaller communities in the province to assist in trade education ${ }^{47}$. Finally, in 1913, Ottawa's report appeared and was made available to the provinces ${ }^{48}$.

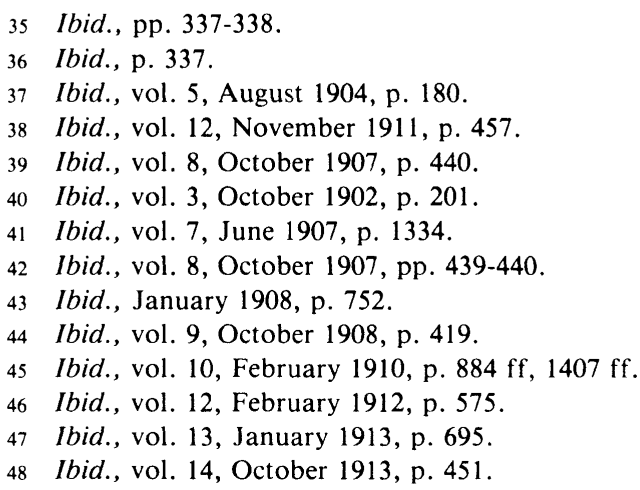


The strike question also demanded action. Short of powerless national unions and the free flow of labour, the answer must be in arbitration, conciliation, or a combination of the two. This in fact the C.M.A. had set out to achieve in its new charter: "The association is also given power to provide for the appointment of arbitrators, members of the association, to hear and decide controversies relating to any commercial matters which may arise between members... or any person whatsoever, which may be voluntarily submitted for arbitration by the parties in dispute." 49 The Association added categorically that the arbitration award was, "to be final and binding upon the parties" (italics mine) ${ }^{50}$. The system was unworkable not only because of categorical right of enforcement of decisions, but because the entire committee was to be formed of members. The C.M.A. could not seriously be regarded as a disinterested body separate from its membership. Similar efforts were made by the Federation of Chambers of Commerce of Quebec in $1910^{51}$, and by the General Contractors' Association of Montreal in $1914^{52}$, with the same limitations.

The C.M.A. did not have the federal legislation of 1900 in mind as it was purely a conciliation scheme. The solution of Mgr. L.N. Bégin to Quebec City's boot and shoe conflict in 1900 must have had some influence on the Association, because of its success, finality of decisions and the popularity it enjoyed at the time ${ }^{53}$. In this case the boot and shoe workers union and the employers' association, deadlocked in a city-wide strikelockout, reached a compromise through the mutually requested intervention of Mgr. Bégin. The solution, which was to be binding on both parties before rendered, involved union recognition by the employers and 'Christianizing' of the union by the workers ${ }^{54}$. This arbitration was also influential in bringing about Quebec's Loi des différends ouvriers in 190155. Indeed Mgr. Bégin recommanded that management and labour create a system of conciliation and arbitration, and Lomer Gouin, the provincial premier, set the process in motion. We know also that the international trade unions looked on the Bégin scheme as a danger and that was enough to recommend it to management ${ }^{56}$.

Other management efforts are also recorded. The Quebec Board of Trade made an attempt at solving the labour problems of the port in Quebec City during 1905: "Negotiations were begun between the Quebec Board of Trade and local labour organizations directly interested in the Shipping business of the port with a view to the organization of a permanent conciliation committee for the settlement of labour disputes arising in connection

49 Ibid., vol. 3, July 1902, p. 33.

50 Ibid.

51 Ibid., vol. 10, June 1910, p. 1350.

52 Ibid., vol. 15, October 1914, p. 428.

53 La Presse, October 26, 1901.

54 WELTON, A., Un orateur apôtre, Mgr Paul-Eugène Roy, Archevêque de Québec (1859-1926), Québec, Éditions de l'Action catholique, 1941, pp. 143-145.

55 GUILBAULT, Jacques, loc. cit., pp. 234-235.

56 Québec, Historique du ministère du Travail et de ses services, extrait du mémoire soumis à la Commission Tremblay, (s.l.n.d.) p. 15. 
with the shipping business of Quebec." ${ }^{57} \mathrm{~A}$ formula for a board of 14 members was presented, and in addition an arbitration board suggested ${ }^{58}$. The same year a joint meeting of the C.M.A. and T.L.C. was held to discuss points of mutual interest, such as the tariff, immigration, and "the establishment of a joint board of settlement of labour disputes, and minimum and collective bargaining between employers and employees with regard to wages and hours of labour" ${ }^{59}$.

There is no further indication of implementation of the plans outlined above. There are, however, three pertinent collective bargaining agreements recorded during the period which indicate long-range commitment between parties and some evidence of initial success. All involve "True Employers' Association" of the first and second categories: "All-Purpose InterSectorial or Sectorial Associations" and "Cohesive Sectorial Associations", according to the Dion model.

The first agreement was signed between the Bricklayers' and Masons' Union and the Montreal Builders' Exchange. The Federal Labour Department obviously expected much of it, because the union was powerful and highly respected: "The moral effect of the endorsement of the principle of arbitration by so important a body should bespeak for the principle (and) the careful consideration of other labour organizations" 60 . Remembering the circulation of the Labour Gazette, it is interesting to note that the terms are quoted in full detail ${ }^{6}$. The specific object of the agreement was to establish an "arbitration and conciliation bureau" for settlement of problems arising between management and labour. The reason: "The serious embarrassments caused to building operations in the city of Montreal by industrial disputes of recent years" 62 .

The second case involved a five-year agreement between the Shipping Federation and the longshoremen of the port of Montreal. A permanent arbitration commission was to be formed to handle all disputes during the five-year period ${ }^{63}$. Later the same year the first two awards were made by the commission, without incident ${ }^{64}$. The third case was an agreement signed between the Canadian Federation of Shoe Workers and the Montreal and District Shoe Manufacturers' Association ${ }^{65}$. It was to continue for three years from January 1, 1905, and involved six manufacturers and over 1,200 workmen.

As a result of the above remarks, it is now evident that business had come to the conclusion that organization and coordinated action were essential during these years, for several reasons. Among them, it is particular-

57 Labour Gazette, vol. 5, March 1905, p. 934.

58 Ibid.

59 Ibid., p. 932.

60 Ibid., vol. 6, August 1906, p. 163.

61 Ibid., pp. 163-164.

62 Ibid., p. 163.

63 Ibid., vol. 10, June 1910, p. 1350.

64 Ibid., vol. 10, June 1910, p. 1350; vol. 11, August 1910, pp. 240-242; vol. 11, September 1910, pp. 326-327.

65 Ibid., vol. 5, May 1905, p. 1225 
ly striking that a comprehensive approach to organized labour began to be felt necessary - even though the latter represented a small fraction of the workforce, and was not overly successful in its confrontations with business ${ }^{66}$. It did exist. It was relatively important. And it had to be dealt with. This beginning of an implicit acceptance of organized labour, albeit grudgingly, offerred a glimmer of hope for pacific labour-management relations toward the end of the pre-war years. It interested all parties concerned, from business, to government and the unions. And it had implications for the legal framework as well as the nature of labour-management relations in the future. The initiative seems to have been taken by various types of employers' associations: but particularly by those directly representative of business in specific sectors of the economy. Heaven on earth had not yet been achieved, as subsequent years were to reveal. It was, nevertheless, a beginning.

\section{LE PUBLIC ET L'INFORMATION EN RELATIONS DU TRAVAIL}

Introduction, Gérard DION - L'information et le public, GÉRARd DION Linformation en relations du travail et le public, PIERRE rTE S.IRTIN Servitudes et difficultés de l'information, THOMAS SLOAN - Lemployeur et l'information du public, GHislain DufOUR - Les syncicats et linformation du public, Richard Daignault - L'Etat-employeur et l'information du public, B.M. ERB - L'Etat-gouvernement et l'information du public, JEAN BERNIER - Les média et l'information du public : la presse écrite, V'inceNr PrINCE - Les média et l'information du public: la presse électronique, GeORges LAHAISE - La presse et le 24ième congrès annuel des relations inclustrielles de Laval, JACQues Rivet et MARCEL GilberT.

1 volume, 226 pages - Prix : $\$ 5.50$

\section{LES PRESSES DE L'UNIVERSITÉ LAYAL}

Cité Universitaire

Québes, P.Q., Canada G1K 7R4

66 An article is shortly to be published on this question by the present author under the title: "L'analyse quantitative de la grève», in an overall study of Québec labour during the two decades preceeding the First World War. 